\title{
Why women own less housing assets in China? The role of intergenerational transfers
}

\author{
Wen Jing Deng $^{1}$ (D) . Joris S. C. M. Hoekstra ${ }^{1} \cdot$ Marja G. Elsinga $^{1}$
}

Received: 9 October 2017 / Accepted: 15 June 2018 / Published online: 5 July 2018

(c) The Author(s) 2018

\begin{abstract}
After three decades of housing reform in China, housing assets constitute a sizable share of family wealth but are distributed unevenly, as registered homeowners are predominantly male. This is partly because males generally have higher incomes than females and can therefore contribute more to the financing, but also because males receive more intergenerational transfers. On the basis of 31 in-depth interviews from Chongqing, this article seeks to answer two questions: (1) How and why does the gender of the recipient affect the negotiation of intergenerational transfers? and (2) What are young women's possibilities to accumulate housing assets? The research findings show that young women either ask their parents for help to secure housing assets before marriage or they attempt to co-own a home with their husbands after marriage. Women who do not succeed in either of these strategies do not accumulate housing assets and thereby risk their rights to the home if their marriage is dissolved.
\end{abstract}

Keywords Housing assets · Home ownership · Intergenerational transfers · Gender inequality $\cdot$ Chongqing $\cdot$ China

\section{Introduction}

After three decades of housing reform, housing assets now represent a significant share of the wealth held by Chinese families, accounting for $37 \%$ of the total amount of the family's private assets which are worth on average CHY 930,000 per household (EUR 102,000 in 2011, Gan et al. 2012). The gender distribution of that wealth, however, is very uneven, as many families register the male household heads as homeowners (Fincher 2014). According to the Third National Survey on the Social Status of Chinese Women in 2010, only 37.9\% of the women own housing property (including those who co-own it with husbands), compared to $67.1 \%$ of the men(ANWU and NSB 2010). Among married respondents, $13.2 \%$ of the women hold the title in their own name and $28.0 \%$ jointly with their spouses, while the shares for married men are 51.7 and $25.6 \%$ respectively (ANWU and NSB 2010). In many families whose

Wen Jing Deng

dengwenjing1984@gmail.com

1 Faculty of Architecture and the Built Environment, Delft University of Technology, P.O.

Box 5043, 2628 BL Delft, The Netherlands 
biggest asset is the housing property, this property is registered solely in the husband's name, even though these properties have also been funded by the wife and her parents (Fincher 2014). Among the unmarried respondents, only $6.9 \%$ of the women own their dwelling while 21.8\% of the men do (ANWU and NSB 2010).

It is thus clear that women own much less housing assets than men. Little literature, however, has tackled the reasons behind this phenomenon. One relevant explanation is that the female partners generally have a lower income than the males (Zhang et al. 2008) and therefore contribute less to the financing of the family home. The average annual income of females is merely $67.3 \%$ of the income of males in urban areas and $56.0 \%$ in rural areas (ANWU and NSB 2010). An often overlooked reason for women to own less housing property lies in the fact that females receive less intergenerational transfers than males (see also Cui et al. 2016). Considering the high price of housing in China, one can hardly afford home ownership without pooling resources derived from family members. This is especially true for young adults, who do not have built up much savings. While some parents make great sacrifices to help a son buy a home, they tend to decline a daughter's request, even if they have the means to help out (Fincher 2014).

The improvement of gender equality in nutrition, health conditions and educational opportunities in China is documented in the literature (Lee 2012). Yet, gender equality in wealth and asset owning is lagging behind. In this domain, the Chinese market reform and the trend towards individualism of property ownership seem to work in the direction of a widening gender gap. At the same time, women's economic security and well-being have become a crucial issue in the rapidly aging Chinese society where the policies hope to boost fertility. Thus, this paper contributes in two ways. First, it reveals the gender inequality in opportunities to accumulate housing assets and the role of intergenerational transfers in this phenomenon. Second, it systematically analyzes the connections between welfare state, family reciprocity, home ownership and gender in the context of China, thereby providing a framework for future comparative research.

In another contribution, we have elaborated on the negotiation processes that underlie intergenerational transfers for the purpose of home ownership (the authors, forthcoming). In this paper, we will investigate how the gender of an adult-child affects these negotiation processes. Utilizing 31 in-depth interviews from Chongqing, this paper answers two research questions: (1) How and why does the gender of the recipient affect the negotiation of intergenerational transfer on home ownership? and, against this backdrop, (2) What are young women's possibilities for accumulating housing assets? The answers to these questions will be framed within the broader system of social coordination outlined above.

The next section presents the conceptual framework of "social coordination" in more detail. Subsequently, we describe the contextual background of China through the lens of this framework. Then, a summary of the research methodology and data collection process is given. The empirical analysis consists of two parts. The first elucidates how intergenerational transfers on home ownership are differentially directed to male and female adult children; the second describes how young women cope with this and elaborates on their possibilities to accumulate housing assets. The final section summarizes the research findings and discusses their wider implications. 


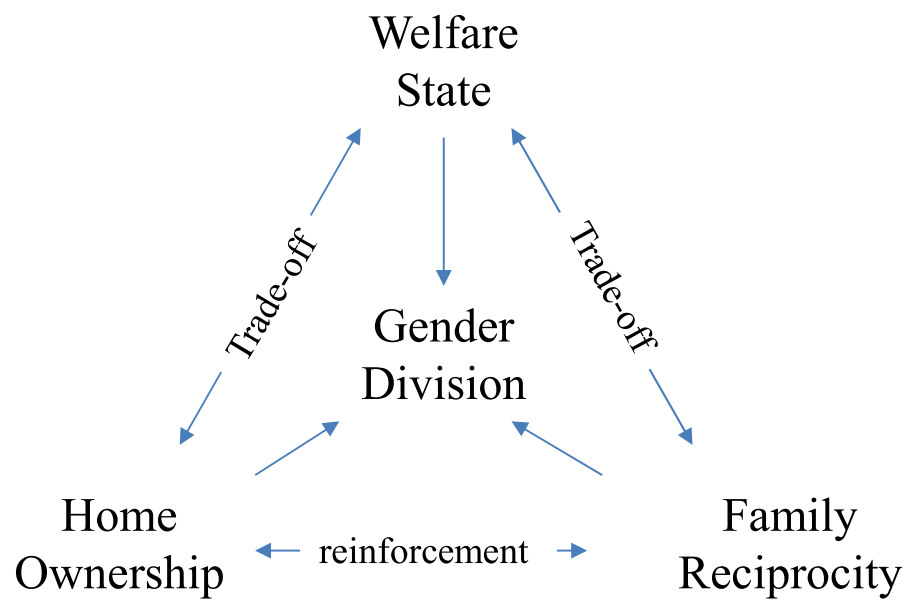

Fig. 1 Conceptual framework

\section{Literature review and conceptual framework}

\subsection{Social coordination of welfare state, home ownership, family reciprocity and gender division}

\subsubsection{The system of social coordination}

Existing research has noticed the substitution effects between welfare state and home ownership, and between welfare state and family reciprocity. When social protection is not available to the public and the generosity of the welfare state is limited, individual households are motivated to accumulate private assets to offset income uncertainty over the life course (Castles and Ferrera 1996; Kemeny 2001; Doling and Horsewood 2011). A common way for families to accumulate assets is home ownership (Dewilde and Raeymaeckers 2008; Toussaint and Elsinga 2009; Doling and Ronald 2010; Elsinga and Hoekstra 2015; Izuhara 2016). Homeowners can reduce the cost of living (by not "wasting money on rent" and living free of charge once they own the dwelling outright) and ensure a safety net to offset financial risks (by cashing out or using the asset as collateral for loans). There is also a trade-off between state and family as welfare providers. Without or with limited public welfare, individuals have to rely on the mutual support of the families, particularly intergenerational reciprocity, to provide care and offset risks in the long term (Croll 2006; Albertini et al. 2007; Blome et al. 2009; Izuhara 2010a). In developing and underdeveloped countries where the welfare state is not effectively established, extended families in which different generations can help each other are common. And vice versa, in developed countries where intergenerational reciprocity is encouraged in culture, such as in East Asian countries, the development of the welfare state is confined (Croll 2006; Izuhara and Forrest 2013; Jacobs 2000). Family reciprocity also works within one generation, in the form of the male breadwinning model; the incomeless wives use their free labor at home to reciprocate their husbands' responsibility in providing cash income for subsistence (O'Connor 1993; Lewis 2002) (Fig. 1). 
In a little developed welfare state with a high percentage of home ownership, family reciprocity in intergenerational transfers of housing property is important. In a homeowner society, access to alternative tenures is limited and living in an owner-occupied home becomes a social norm (Ronald 2008). A high demand for home ownership coupled with insufficient access to the rental sector may drive up the price of owner-occupancy properties. As a consequence, home ownership is often unaffordable for young households unless they receive support from parents and/or other family members (Izuhara 2010a; Heath and Calvert 2013; Druta and Ronald 2016; Manzo et al. 2016; Deng et al. 2016). Parents are usually inclined to help out, as home ownership is a good investment for the family and their help could evoke reciprocity from their children, which is the major source of support in old age when welfare state provisions are limited (Izuhara 2010b; Zhong 2014, or 2017).

We call the interconnectedness between welfare state, home ownership and intergenerational reciprocity discussed above "social coordination", as it illustrates how individuals, families, and the state are connected in a society (through the lens of housing).

\subsubsection{Home ownership, family reciprocity and welfare state in China}

In another publication (the authors, forthcoming), we document how reciprocity works in smoothing the exchange between parental help in accessing home ownership and the children's support in old age care. The expectation of reciprocity plays a key role in deciding whether an intergenerational transfer takes place. Basically, the parents only make the transfer when they view the beneficiaries as trustworthy providers of old age care. Some adult children, under the purpose of maintaining their autonomy in deciding an acceptable level of filial duty, refuse or avoid asking for support of their parents. The reciprocity expected by the parents can be financial, instrumental, or emotional, depending on the needs of the parents and the availability of the children in due time. This exchange is not to be explicitly discussed during the process of negotiation, but it is well understood and perceived justified by the adult children. We also observed an influence of the welfare state on the motivation of intergenerational transfers. In the current Chinese welfare system, rural residents receive far less state welfare than urban residents. This motivates them to invest more in intergenerational reciprocity, while the urbanites can be more altruistic in the transfer. Households with a rural migration background are more willing and more likely to feel responsible for supporting their children in getting access to home ownership than their urban peers, even though they have fewer resources to do so.

\subsubsection{The role of gender}

In this paper, our main concern is to add another dimension in the triad of social coordination-gender. Gender divisions are important in the understanding of how individuals, families and the state are organized in a particular society. In most of the preindustrial societies and to a lesser extent but far from extinction in the industrialized societies, production and property ownership are organized along lines of gender. The men work outside the family as the "bread-winner" and represent the household in public. They are recognized by the community and the authorities as the "head of the household" and the owners of family properties. Women, on the contrary, provide services and care within the household without any monetary compensation. They are viewed as dependents of their husbands and fathers, which implies that they cannot hold properties (Engels 1884; Goode 1963; Hareven 1999; Whyte 2003). The gender 
differences did not disappear when welfare states started to develop and social protection became a civil right. After all, the organization of social protection is often gendered as well. Many modern welfare states (with exceptions in Scandinavia) are still based on the male breadwinner model in which the male workers receive a "family wage" to support their wives staying at home and doing unpaid house and care works (O'Connor 1993; Orloff 1993; Esping-Andersen 1990, 1999; Lewis 2002; Leitner 2003).

After decades of feminist movement and progress in social policies, gender gaps in education and income have in different extents diminished in many developed and developing countries. Yet, the gender gaps in the distribution of property and assetholding remain persistently large (Deere and Doss 2006; Kennett and Chan 2011). Direct or indirect discriminations affect women in the distribution of proprietary resources in both private and public spheres, such as in inheritance of properties (Kennett and Chan 2011), in registering the ownership of housing, in taking mortgage loans (Izuhara 2015), in the distribution of land (Sargeson 2012b) and in the allocation of social housing (Guo 2011). Female-headed households in particular experience significant disadvantage in terms of accessing and sustaining appropriate housing (Kennett and Chan 2011).

In next section, we will apply the perspective of social coordination and examine how welfare provision, family relations and housing are linked in the context of traditional and contemporary China.

\subsection{Social coordination in China: from past to present}

\subsubsection{Social coordination in traditional Chinese society}

In traditional Chinese society, the provision of housing (and by extension the ownership of housing property) was always associated with elderly care and generally arranged patrilineally (Logan et al. 1998; Whyte 2003). In a patrilineal society, marriage is normally patrilocal; residing matrilocally is deemed socially undesirable. Patrilocal means that the groom's parents prepare a space so the new couple can move in with them and become co-resident. After marriage, the bride becomes a member of the groom's family and will care for her husband's parents rather than for her natal parents. The children of this couple would also be named according to their father's genealogy. In this way, a Chinese family is reproduced patrilineally. Housing, both as living space and property, is an important link in this chain of reproduction. A home is both a practical place (for caregiving) and a symbolic space (in which one identifies with a family network). In this way, providing housing, either financially or in-kind, justifies the providers' rights to care and enables them to receive it (Logan et al. 1998; LaFave 2016).

Consequently, in traditional Chinese society, there is a preference for sons. Only sons are considered permanent members of the family and the source of care. As a result of this, girls receive much less from the family in terms of resources and investment (Song 2008; Li and Wu 2011). They receive less nutrition than boys and they carry out duties within the household from a very young age. They are relatively deprived in terms of formal education and human capital accumulation. 


\subsubsection{Social coordination in contemporary China}

The Feminist movement in the twentieth century campaigned for gender equality and women's access to civil rights such as freedom of marriage and divorce, right to education and formal occupation, and right to acquire and maintain properties. The Communist regime particularly promoted women's participation in the labor force and gender equality in allocating job opportunities, as means of mass mobilization and means to facilitate industrialization (Davis and Harrell 1993; Zheng 2005).

\subsubsection{Chinese welfare state}

From 1949 and onwards, a nationwide welfare system was gradually developed. It started in a very preliminary form, covering only state employees, and gradually expanded into a somewhat more comprehensive system. The current Chinese welfare system has eligibility criteria based on formal employment and benefits based on contribution, which means that women can only gain access to social benefits if they are paid workers and contribute to the social security fund. As a result of lower female participation in the labor force and lower pay scales, only $54.1 \%$ of the elderly females in the cities have pension, compared to $79.3 \%$ for their male counterparts. In the countryside, the gap is even wider: $38.8 \%$ for females and 59.1\% for males (ANWU and NSB 2010).

Even though gender equality is still on the official political agenda, state institutions in many domains are suppressing women's rights toward land and housing, under the assumption that they will get it from their husbands (Guo 2011). Women have been more vulnerable than men to forced acquisition and have had to protect their land rights, though with far less success than men. In 2010, $21.0 \%$ of the rural women were landless, 9.1\% higher than the rate for rural men (ANWU and NSB 2010). Furthermore, current Chinese laws do not provide mechanisms to distinguish women's property rights within the household. Therefore, if the marital status of a woman changes, her rights to family property such as land and housing can be easily infringed (Sargeson 2012).

\subsubsection{One-child policy and family reciprocity}

From 1982 and onwards, China launched the so-called "one child policy", stipulating that in principle each couple should only have one child. This policy is applied strictly in urban areas but somewhat more loosely in rural areas (Zhang 2007). As a result of the policy, the fertility rate dropped from 2.7 in 1986 to 1.5 in 1997 and has since remained stable (World Bank 2017). A line of research suggests that the one-child policy reduced the number of competitors for a family's resources and improved gender equality to some extent. Under this policy, single-child girls and girls with only female siblings receive more education than girls with male siblings (Tsui and Rich 2002; Lee 2012). Many families, even from rural background, started to encourage their daughters to pursuit a career and provide help such as child care (Xiao 2014; Ling 2017). However, the improved gender equality is not yet visible statistically in the allocation of family property and assets. Even though the inheritance rights of daughters are written in law, inheritance allocation only to sons still dominates in rural areas (Sun 1996; Wu 2012). 
A survey from the 1990s showed that only $40 \%$ of urban residents and $14 \%$ of rural residents agree with shared inheritance among daughters and sons (Sun 1996).

Post-reform policies pay more attention to the protection of individual property rights and interests. Different from family policies in the socialist era which emphasized protection of women, current policies highlight the financial contribution and rights toward the family assets of the breadwinner and loosen the rights of the female homemakers. As divorce rates and disputes over marital property rise, a new judicial interpretation of the Marriage Law was issued in 2011. This new interpretation stipulates that the housing property (or a share of the housing property) paid by one spouse (including parents of the spouse) before the wedding belongs to the payer (Supreme People's Court 2011) In recent years, with children that are born under the one-child policy reaching marriage age, new dynamics were introduced in family relations and power structures. The existence of families with only daughters challenged the patrilineal family reproduction model, as parents in these families also need care from the daughters and sons-in-law; the parents of the bride and groom have to compete for priority in their children's future caregiving. Considering the direct linkage between the surname of the grandchild, housing provision and rights to care, some parents of the brides insist to finance the new couple's home in order the gain the right of surnaming and future care (Qi 2017). If the parents contribute significant amounts to their children's home ownership, they are not only more likely to arrange a desirable location at which they would eventually receive care but are also holding the moral high ground, either to claim their children's reciprocal care or to use part of the equity stored in their children's home to pay for institutional care and health treatment (Zhang 2004; Luo and Zhan 2012; Sun 2012; Zhang et al. 2014). Thus, a gendered relation of housing intergenerational transfer and age support can no longer be automatically assumed. Instead, case-by-case negotiations become the norm. In such negotiations the financial ability of the bride or groom's parents, the affection between adult children and parents, and the geography of their residence, play a crucial role.

\section{Research design ${ }^{1}$}

Chongqing has been the international trade and administrative center of Southwest China since the 19th century and was the capital city from 1937 to 1944. The core area, Yuzhong District, has been occupied by families established there for generations. They were employed in the administrative, trade, and service sectors and lived in crowed privately owned homes. During the 1960s, Chongqing experienced rapid state-led industrial development and has since established itself as one of the centers of heavy manufacturing in Western China, with more recent settlers working in state-owned factories. During the economic reform of the 1980s and 90s, many immigrant workers came from nearby rural areas and found informal employment in the rapidly growing private sector. Being one of the four cities controlled directly by the central state (the other three are Beijing, Shanghai, and Tianjin) and the only one in inland China since 1997, Chongqing's vigorous development has attracted many migrants with high educational qualifications from both rural and urban areas. In our study, we approached all three groups-the locals, urban migrants, and rural

\footnotetext{
1 Sharing the same data and research methods, this research design Section has the same text as another paper by the authors (forthcoming).
} 
migrants - as the public welfare systems they have entered were different. The state workers enjoy the best public welfare and receive support for education, career development, and housing from the state. The established residents working in the private sector receive less from the state but can fall back on the family resources accumulated over generations. Finally, new migrants that have arrived after the economic reform tend to receive less state support (often because they don't possess a local urban hukou) and their earning capacity varies according to their educational qualifications.

The fieldwork was conducted in the metropolitan area, consisting of nine districts with an approximate area of $500 \mathrm{~km}^{2}$ and a population of eight million (2010, sixth census). The data was collected in November and December of 2015 and 31 participants were interviewed with the help of a semi-structured interview guide. The interviews were started with an information table collecting a range of basic information: (1) the demographic and socio-economic status of each member of the extended family; (2) the housing history from birth, including the time period, location, dwelling type, dwelling size, affordability, tenure situation, and living arrangement for each period of occupation; (3) the payment structure of the first and current (if they are not the same) dwelling, i.e. who pays for what percentage of the total value. The semi-structured interviews also addressed the following two topics: (1) the process of home purchase, particularly who initiated the purchase and how the payment structure was negotiated and settled; (2) the perception of and attitude towards intergenerational transfers, both within the own family setting and in general terms. The semi-structured interviews lasted from 45 to $75 \mathrm{~min}$, depending on the complexity of the story. The language used in the interviews was Mandarin or the local dialect. Immediately after the completion of the interview, the interviewer wrote up a short summary of the participants' opinions and relevant non-verbal impressions. All interviews, except two ${ }^{2}$, were recorded and subsequently coded using Atlas.ti 7.0. The participants were given numbers so that they can remain anonymous, and quotations from their responses have been translated from Chinese into English.

The participants were selected by a purposive sampling method under the principle of maximum diversity. First, we targeted and categorized three groups of young people: locals, urban migrants (who moved from one urban area to another), and rural migrants (who moved from the countryside to the city) (see Appendix 1 for more details). Second, within each group we recruited a sample with maximum diversity in terms of age, gender, occupation, education, income level, life course, housing and living arrangements (e.g. living independently or with parents; having renting experience or not) and intergenerational transfer experience (e.g., did or did not receive intergenerational transfer; asked/did not ask for intergenerational transfer). In a few cases, both partners of the couple were present during the interview and they were registered as one case. Parental participants were recruited along the same lines. We recruited parents with a range of experiences with regard to equity transfers (i.e. transferred, did not transfer, did not transfer but plan to do so in the future). A minority of the parental participants were parents of young adult participants that were also recruited. In such situations, parents and young adults were interviewed separately from each other. More details on the participating parents can be found in Appendix 2). Participants were approached through snowballing method, starting with personal contacts. This approach was taken because the topic of this research is both private and sensitive and recruiting from a pool of acquaintances helps build trust.

\footnotetext{
${ }^{2}$ Case 05 refused to be recorded and the recording of Case 14 failed due to a problem with the equipment. The analysis of these two cases was done on the basis of interview notes. Detailed written notes were taken during the interview of Case 05. For Case 14, some important questions had to be answered again. For this purpose we used WeChat, a social media app that enables voice messaging.
} 
Table 1 Summary of young adult research participants

Table 2 Summary of parental research participants

\begin{tabular}{llllll}
\hline & Male & Female & Couple & Total & $\begin{array}{l}\text { N. } \\
\text { transfers } \\
\text { received }\end{array}$ \\
\hline Local urban & 4 & 2 & 2 & 8 & 5 \\
Urban migrants & 3 & 2 & 1 & 6 & 3 \\
Rural migrants & 4 & 2 & 2 & 8 & 3 \\
\hline
\end{tabular}

\begin{tabular}{lll}
\hline & Total & $\begin{array}{l}\text { N. } \\
\text { transfers } \\
\text { provided }\end{array}$ \\
\hline Local & 6 & 3 \\
Migrants & 3 & 3 \\
\hline
\end{tabular}

We kept on recruiting research participants in these three groups with an eye to variety in other respects until information saturation was reached. At that point, information from participants started repeating itself, and no new themes pertinent to our research questions came to the fore, even when new participants with a different background were recruited. In total, 22 young adults aged from 24 to 41 and nine parents aged from 49 to 60 were interviewed. Eleven of the 22 young participants had received an intergenerational transfer from their parents. Of the nine parents that were interviewed, six had provided an intergenerational transfer to their children (see Tables 1 and 2 for a summary of the research participants and Appendices 1 and 2 for more details).

\section{The gendered intergenerational transfer of housing assets}

The patrilineal tradition leads to different strategies for saving and housing planning with salient differences between families with male or female children. Families with male children would plan a home for the sons well in advance of marriage and start saving money for that purpose. Families with female children, on the other hand, rarely make any proactive financial arrangements. However, on top of gender family size matters as well, as the next two Sections will show.

\subsection{In multi-child families}

If a family has both male and female children, which is the case for many rural migrants, the parents only prepare for their male children's home.

In our home town, it is all like this. Parents would prepare a home for their sons. Houses are cheap in my home town, so my parents just bought a home for my two brothers. It is more expensive in Chongqing, so my mom can only help me with mortgage down payment. ... No help to daughters. In my home town, normally parents wouldn't support daughters as they will marry out. (Case 11, male, age 37, engineer, migrant from a northern province) 
However, for young migrants who plan to buy a home and settle down in the city, resources received solely from the man's family are often not enough. The young couple would ask for help from the wife's family too. In such circumstances, resources from the husband's parents are often a gift, while help from the wife's family is implicitly an interest-free loan.

(Male participant:) After we decided to buy a home, we asked our parents with how much money they could help us. My parents gave me all their savings, so after the home was ready they move in with us and left their rural home. (Female participant:) But in my family, this is a loan. I borrowed from my parents, my brother, and my sister. We repay them later. (Case 21, a couple from nearby Sichuan Province, both age 36 , own a company together)

A gift from the male's side and a loan from the female's side form a combination that also applies to Case 21. As the research participants point out, this combination is a direct result of the patrilineal tradition and the linkage between parents' housing duties and adult children's elder-care responsibility.

(Male participant:) I think this has something to do with the traditional household structure. Because my wife is daughter and her parents, from deep of their heart, believe that they should rely on their son for age support. (Female:) It also has something to do with the culture. For home purchase, traditionally it is the responsibility of the male's family. The female's family would not be taking care of this stuff. Even nowadays in many single-child families. (Case 21, a couple from nearby Sichuan Province, both age 36 , own a company together)

\subsection{In single-child families}

The female participant in Case 21 is correct in suggesting that even in those single-child families from an urban background, a gender discrepancy still exists. Parents of a male child start planning for their son's home a long time in advance. If their financial situation allows it, these young men become homeowners when they are still in college or immediately after they start their first job. Often, it is the parents who come up with the down payment and the young men pay the monthly installments on the mortgage. After marriage, the wives of these home-owning young men would move in with them.

My parents paid the (mortgage) down payment. I paid the monthly installment. Our main purpose is to prepare a home for future marriage. Another motivation is investment. (Case 07, male, age 31, manger in a department store)

After I graduated from college and start to work in this hospital, my parents offered me all their savings and asked me to buy a home. (Case 05, male, age 33, facility manager in a hospital)

Families with only daughter tend not to plan for their child's future home, as they consider it the responsibility of her future husband's family, but some parents register their daughter's name as the proprietor of their own home. Unlike similar behaviors in families with a male child, these homes are not devoted to the daughter's use for independent living or marriage. It is more like a strategy to secure support from the daughter, by assuring the property as bequest in the future. 
I think my daughter's and her husband's home is her husband's family's responsibility. We can contribute a share, but her husband's family should contribute more. (Case P02, male, age 60, retired as a technical manager in a joint-venture factory)

My parents won't buy a home for me. They think, after marriage, it is the husband's responsibility.... But they registered their home under my name. That is to avoid transfer costs in the future, but it is still their home. I never feel that is my home.... After my divorce, my father did not allow me to use it because he did not want me to divorce. (Case 02 , female, age 34 , administrative staff in a private company)

In Chinese culture, the male children are primarily responsible for providing old age care to their parents. It is in exchange for this responsibility that they receive intergenerational transfers. However, in situations where male age supporters are not available, such as in multi-children families with no sons or in single-child families with only a female, it is possible for female children to receive such transfers. This is most clearly illustrated by Case P8's explanation on why she insists on helping both her daughters in acquiring home ownership.

I have to prepare some money for my old age. And we should also help my younger daughter (in home purchase) since we had helped our older daughter. ... We don't have that fortune to have a boy, the only thing we can do is to help our daughters. Nowadays the duty of supporting aging parents is the same for sons and daughters. (Case P8, female, age 58, waitress in a small restaurant, migrated to Chongqing several years ago)

\section{Young women's opportunities to accumulate housing assets}

Even though parents with female child(ren) rarely take the initiative for providing intergenerational transfers, there is room for young women to negotiate and maneuver. This section describes three different possibilities that young women have to accumulate housing assets. Based on the availability of parental support and their own earning power, some young women secure housing assets independently before marriage while others secure assets together with their partners after marriage. Finally, in the absence of parental support and own earnings, some women cannot accumulate any assets and therefore become financially dependent on their partners. Below, each of these three situations are described in more detail.

\subsection{Seek help from parents}

Some of the young women in our research successfully established independent home ownership while they were unmarried. This means that no matter what happens to their marriage in the future, whether they remain unmarried or get divorced, their residence and financial safety net is stable. They can hardly establish such a position without parental transfers, however. In other words, an independent housing asset for women usually means independent from husband and marriage but in fact dependent on parents. This is nevertheless a privileged position for young women and requires the concurrence of several circumstances. In our research, the cases 03,13 , and 14 belong to this group. They all have an urban background and are the only child in their families. They are the initiators of the intergenerational transfer that they received from their parents, with which they have a close relationship that is characterized by a high level of trust. 
I know that housing prices in China, also in Chongqing, will rise. And my working place is far away from my parents' home. It took me one hour one way, very inefficient. So I proposed to my parents that I want to buy a home. And I convinced them. (Case 03, female, age 32, an asset manager in a commercial bank)

After I decided to settle down in Chongqing, I immediately started home viewing and I asked my parents to help me. ... I think a woman should have her own home, although people said the man will provide you with accommodation after marriage. But I would feel unsecure if I would not have my own home. My relationship with my husband is good, but I still want my own home. (Case 13, female, age 34, designer in a State-Owned Enterprise)

One important reason why these women received support from their parents lies in their mothers' personal experience in the patriarchal families and their concern for their daughters' financial independence in marriage.

Our idea as parents is to prevent the man from looking down upon our daughter, from putting financial pressure upon our daughter. My daughter shouldn't be financially dependent on her husband. (Case P1, female, age 58, retired as an administrative staff employee)

\subsection{Co-owning with husbands}

If owning a home before marriage is not feasible — and that is very often the case-buying a home together with their husband and becoming a co-owner is another possibility for married women to accumulate some housing assets. In order to claim a share in home ownership, either the wife or her parents (such as Case 06) would need to contribute a share of the purchase price. When young women want to use their own income (such as Case 21 and 22), they would probably only have the chance to do so if the couple were to decide to buy a second home and if they had sufficient income to do so. That is because many young men already own a home before marriage. And these homes, in most cases, are fully paid for by the husband's parents or jointly by the husband and his parents. Thus, the couple's motivation to buy a second home, other than for holidays, upgrading or investment, would be to strike a balance between the financial interests and powers of the husband (and his parents) and the wife (also see Zhong 2014, 172).

We purchased another home earlier this year. The home we currently live in is, after all, purchased by my husband and his parents, but the new home is ours [my husband's and mine]. (Case 05, female, age 31, civil servant)

Making a financial contribution is not the only way to justify a woman's claim to the marriage home. As women play a major role in unpaid housework and care, in the view of many men and women such services justify women's rights to family property.

Although my income is much lower than my husband's, I don't feel inferior to him. He makes money outside, but all the domestic work like child care depends on me. He offers money and I offer labor. (Case 02, female, age 34, administrative staff employee)

I think if the woman wants to have a share in the marriage home, she should share the responsibility. It does not mean that this woman must work, but she should fulfill 
her duties at home, for example taking care of the child and the elders. (Case 11, male, age 41, project manager in a real estate development company)

In some cases, women get 'compensated' for their domestic services and chores by getting access to the assets that are accumulated in the house in which they live. Consider, for example, the first marriage of Case 16 and Case 02's current husband. Although the husbands brought in the full amount of money that was needed to purchase that marriage home, they registered their first wife as the only owner. And thus, after the dissolution of their first marriage, the property went to their ex-wife. Case 16 explained his rationale like this:

Women are more vulnerable. Let's say if our marriage didn't work out, as a man, even if I am 50 years old, I still have chances. But for a woman, where does her sense of safeness comes from? Only from the man. Besides her man, what else she can count on? (Case 16, male, age 41, business owner in tourism)

However, justifying home ownership through a woman's care and services is not standard institutionalized behavior. Only if the husband voluntarily registered the wife as the home owner at the moment of purchase and does not retract this registration in a divorce court afterwards (which he could do by proving payment), the woman has a right to the property concerned. Thus, a woman's ownership or co-ownership through domestic service is at the mercy of the man. It is thus important for women who do not have parental support in asset transfer, and particularly so for those who do not get good pay in the labor market either, to select a financially capable and virtuous husband.

I won't consider a man who doesn't have a high income. But it is not only about income, it is also about his moral quality. I am lucky. I have dated my current husband in high school. He raises no suspicions in me. He has a good income and he is willing to support me financially. When the kids approached the age of school, he said we should buy a home and let our child go to a good school. So he bought a home and registered me as the owner. (Case 02, female, age 34, administrative staff in a private company)

\subsection{Dependent wives}

Women who did not receive parental help and did not make a direct financial contribution to the home generally do not accumulate housing assets. Instead they depend on their husband's housing assets. If the marriage is stable, there is no problem. But if anything goes wrong and the marriage breaks up, these women may end up without any monetary compensation. Thus, non-owning wives are more vulnerable in the marriage than owning wives. Fearing homelessness, some women are forced to stay with a violent partner or in an unhappy marriage (Fincher 2014).

In my first marriage, my ex-husband's mom purchased a home for him. So after we married, we moved into that dwelling. Then after I divorced him, I moved out. (Case 02, female, age 34, administrative staff)

After my older sister got divorced, she is in hardship. So I invited her to live in our home and we support her spending. I helped her to look for jobs and her daughter coming to study in Chongqing. Now she has found a stable job and she has moved out. (Case 21, male, age 36, business owner) 
Some women miss the chance to make a financial contribution to the marriage homefor example, if this home has already been purchased outright by the man's parents. For these women, it is very hard to reverse the situation, even if they have a paid job. Purchasing another home is the only option open to this group. This is exactly the situation Case 02 faced in her first marriage. Since the husband already owned a home and had no immediate incentive to buy another one, the wife needs to have substantial earning power to initiate such a purchase and/or at the same time be able to convince her husband or parents(-in-law) to contribute too. Because women are mostly responsible for the housework, their income is usually spent on daily consumption (such as food) rather than saved up to buy another home.

The parents play an important role in helping young women with the accumulation of housing assets. Not only can they give financial assistance, they can also offer child care, thereby enabling the young women to continue a full-time career. Because there is almost no public child care in China and private child care is expensive and untrustworthy, many families rely on grandparents to care for young children (Xiao 2014). If, for reasons like health or migration, the grandparents are not available, the young mother would have to stay home to take care of the child. In this situation, the woman would make no financial contribution to the household, so it may be harder for her to claim a share in the family assets, especially when the husband is struggling to shoulder the housing costs alone.

We asked if my parents-in-law would like to move in with us and help us with child care. But they don't want to. They don't want us to be too dependent on them. So my wife stayed at home for child care.... When we were buying our marriage home, it was so hard. I asked help from my parents-in-law but they didn't help us. They are not rich either. I have no choice. My name is on the property certificate, so I have to work hard and repay the mortgage debt by myself.... So now I am the owner of our home. (Case 12, male, age 37, immigrant from Jiangxi Province)

\section{Conclusion}

The literature shows that parental background and the availability of intergenerational transfers largely determine the chances that young adults will be able to attain home ownership. This paper has elucidated the mechanisms underlying these factors by exploring the relationship between intergenerational transfers and gender. We chose to position our empirical study in China, a country with severe housing affordability problems and a persistent patrilineal family tradition. The empirical study for this paper was carried out in Chongqing, Southwest China. Although we don't claim that Chongqing is representative for China as a whole, we do think that the mechanisms that are described in our paper have a broader relevance for Chinese society. Utilizing 31 in-depth interviews from the city of Chongqing, we investigated two questions: (1) How and why does the gender of the recipient affect the negotiation of housing-asset intergenerational transfer? and, against this backdrop, (2) What are young women's possibilities to accumulate housing assets?

Our study in Chongqing has elucidated the gendered practice of intergenerational transfers for home ownership in China. In multi-child families, parents prepare for and transfer housing assets to sons prior to or at the moment of marriage, whereas they would at best provide interest-free loans to daughters upon request. In single-child families, parents would not prepare a housing-asset transfer for their daughters, as they expect their daughter's future husband and his family to do so. Under these circumstances, ownership of housing assets before marriage 
is much less common among women than among men. And not only do women bring fewer assets into the marriage, they also have a disadvantaged position in the labor market. Therefore, the family home is often in the possession of the man and the accumulation of housing assets during the marriage is difficult for women. Consequently, women face the risk of losing access to their family home and being without assets if their marriage status changes.

Against this background, young women in Chongqing embark on three different scenarios for housing asset accumulation, based on their parental resources and their own earning power. When parental help is available, some young women successfully establish independent housing assets while they are still single. Their control over these assets is not subject to changes in their marriage status. Furthermore, without utilizing parental resources, women can still establish co-ownership with their husband by sharing in the mortgage payments. In many cases, however, a woman can only become a co-owner if the couple buys a second home, as the first one is often purchased by the husband and his parents. Finally, some women, do not possess any housing assets. For them, not only is financial help from parents out of reach, but their own earning power is constrained by the fact that they have no help with child care and household chores.

The social status of Chinese women has improved substantially in the last half a century due to the economic independence they get from labor market participation. At the same time, their lagging behind in holding housing assets becomes a new source of inequality. Our research shows that women's disadvantage in holding housing assets is not only caused by their lower earning power in the labor market but also, and probably more so, by gender discrimination in the provision of intergenerational transfers. This discrimination is rooted in China's traditional patriarchal power relationships. These relationships were mitigated by the socialist movement between the fifties and the seventies but are coming back now that private ownership of housing has become the norm. In the post-reform Chinese social coordination system, there is an increased emphasis on family reciprocity and home ownership, which reinforces the gender gap in housing asset-owning between men and women.

In this paper, we introduce the conceptual framework of social coordination and we use this framework to analyze how Chinese men and women have differentiated opportunities to access home ownership and to accumulate housing assets. This framework uses a holistic approach to analyze the mutual influences between welfare state, family reciprocity, home ownership and gender. Future analyses based on this framework may help to understand how social policies and housing policies influence gender relations and fertility rates, or to understand how gender divisions influence the sustainability of the housing system and welfare state. The social coordination framework can also be helpful in comparative studies that aim to explain the different institutional choices and outcomes of different countries.

Acknowledgements Funding was provided by China Scholarship Council (201306260142).

Open Access This article is distributed under the terms of the Creative Commons Attribution 4.0 International License (http://creativecommons.org/licenses/by/4.0/), which permits unrestricted use, distribution, and reproduction in any medium, provided you give appropriate credit to the original author(s) and the source, provide a link to the Creative Commons license, and indicate if changes were made.

\section{Appendix 1}

See Table 3. 


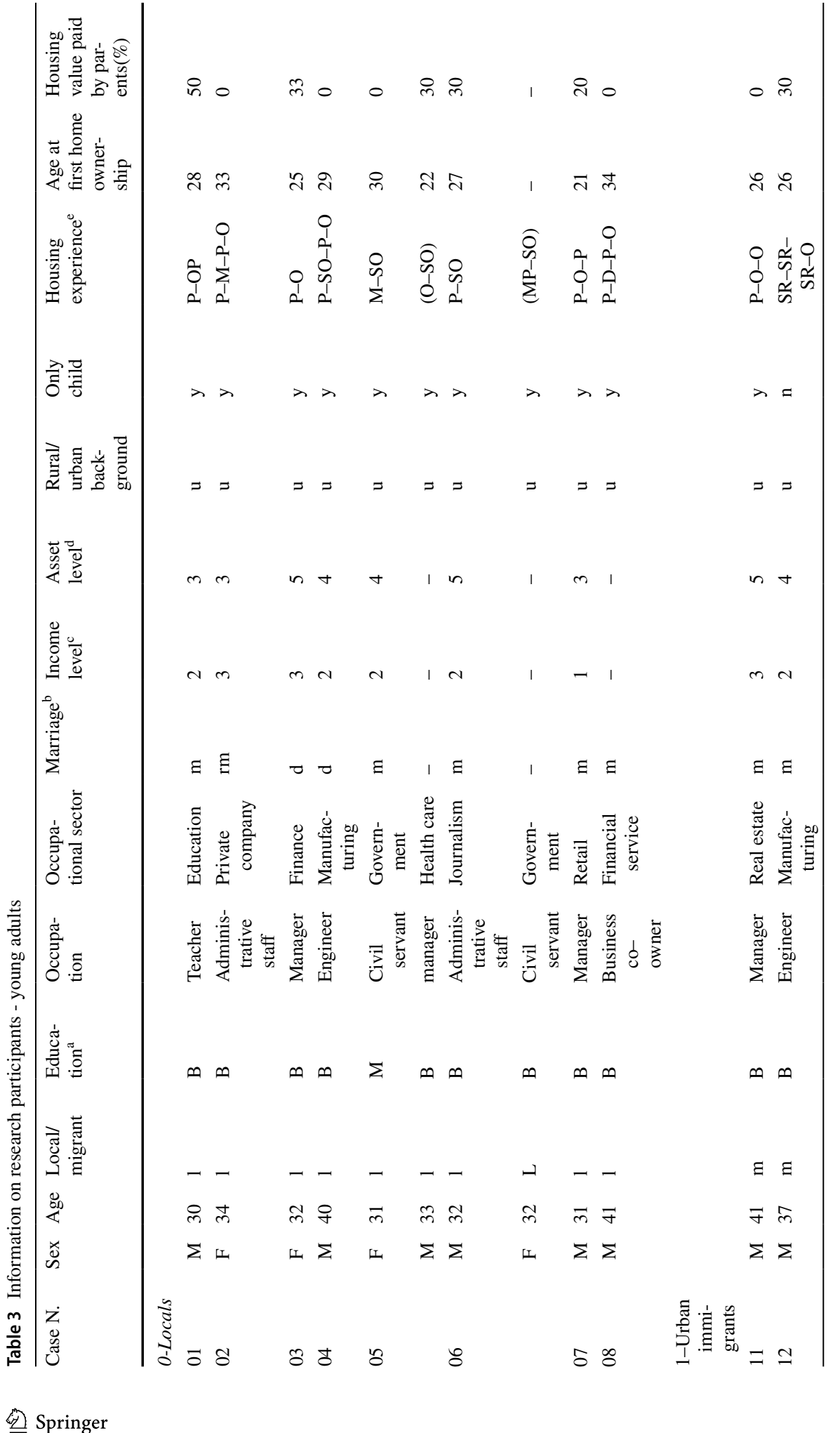




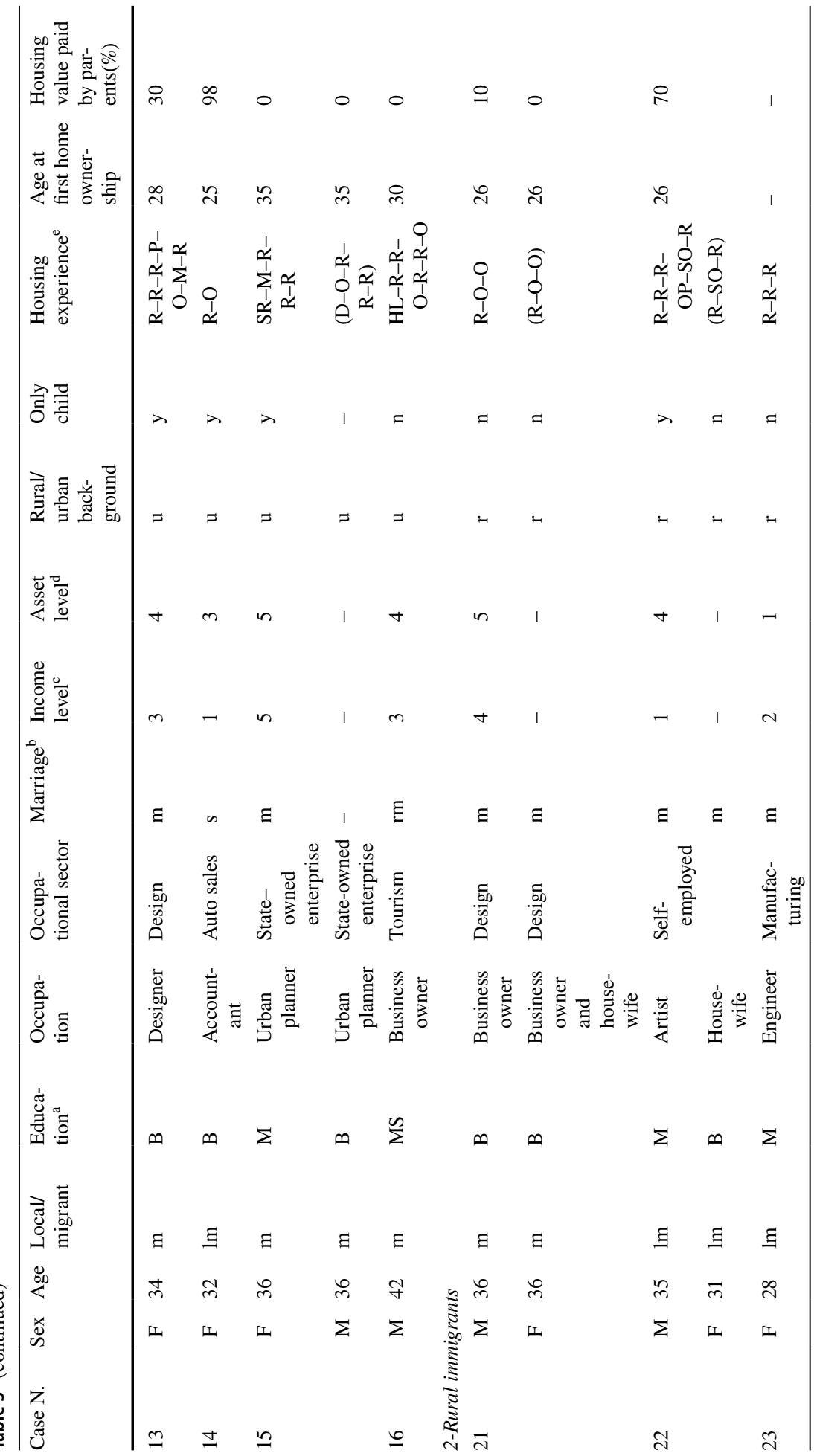




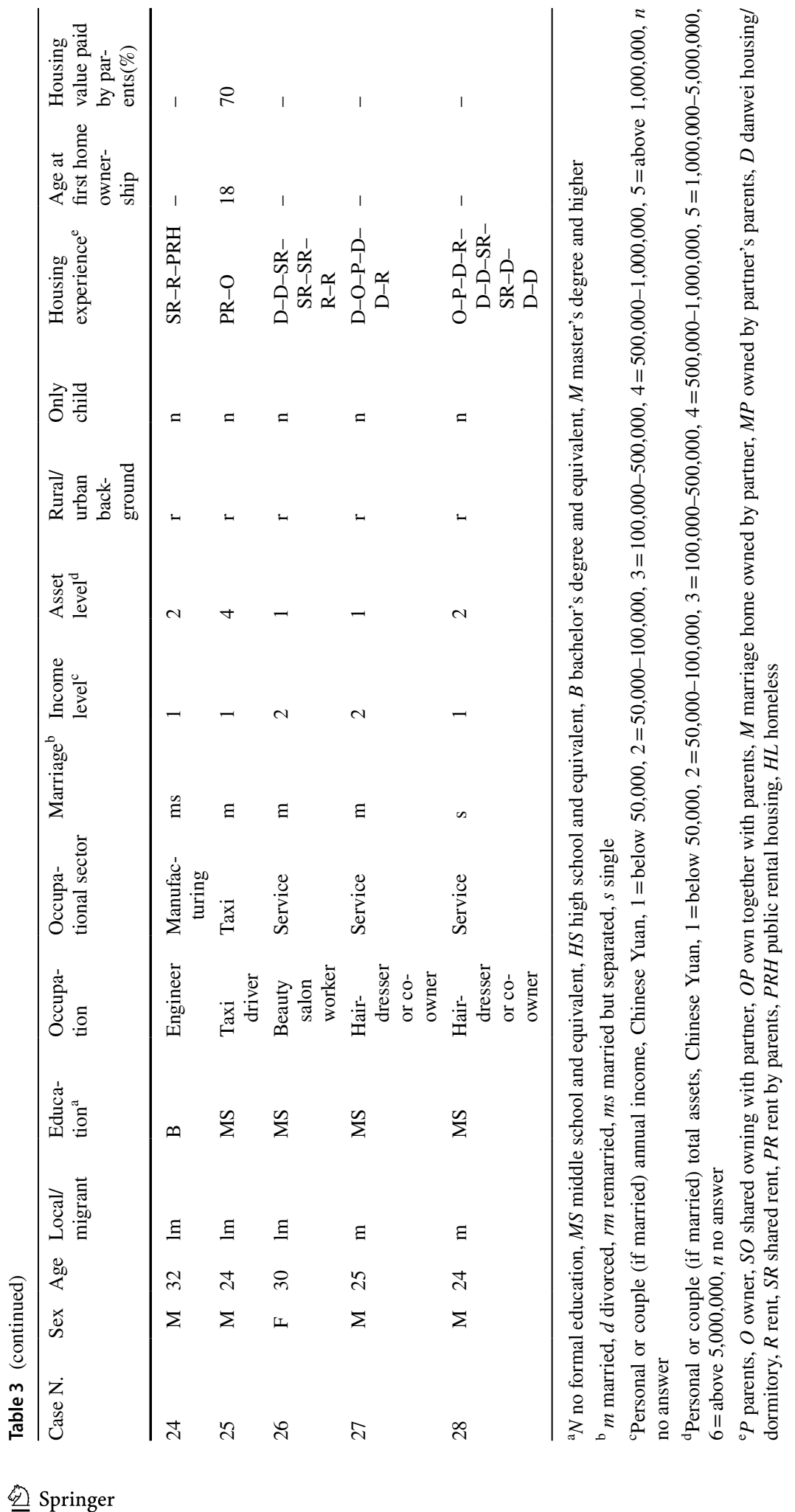




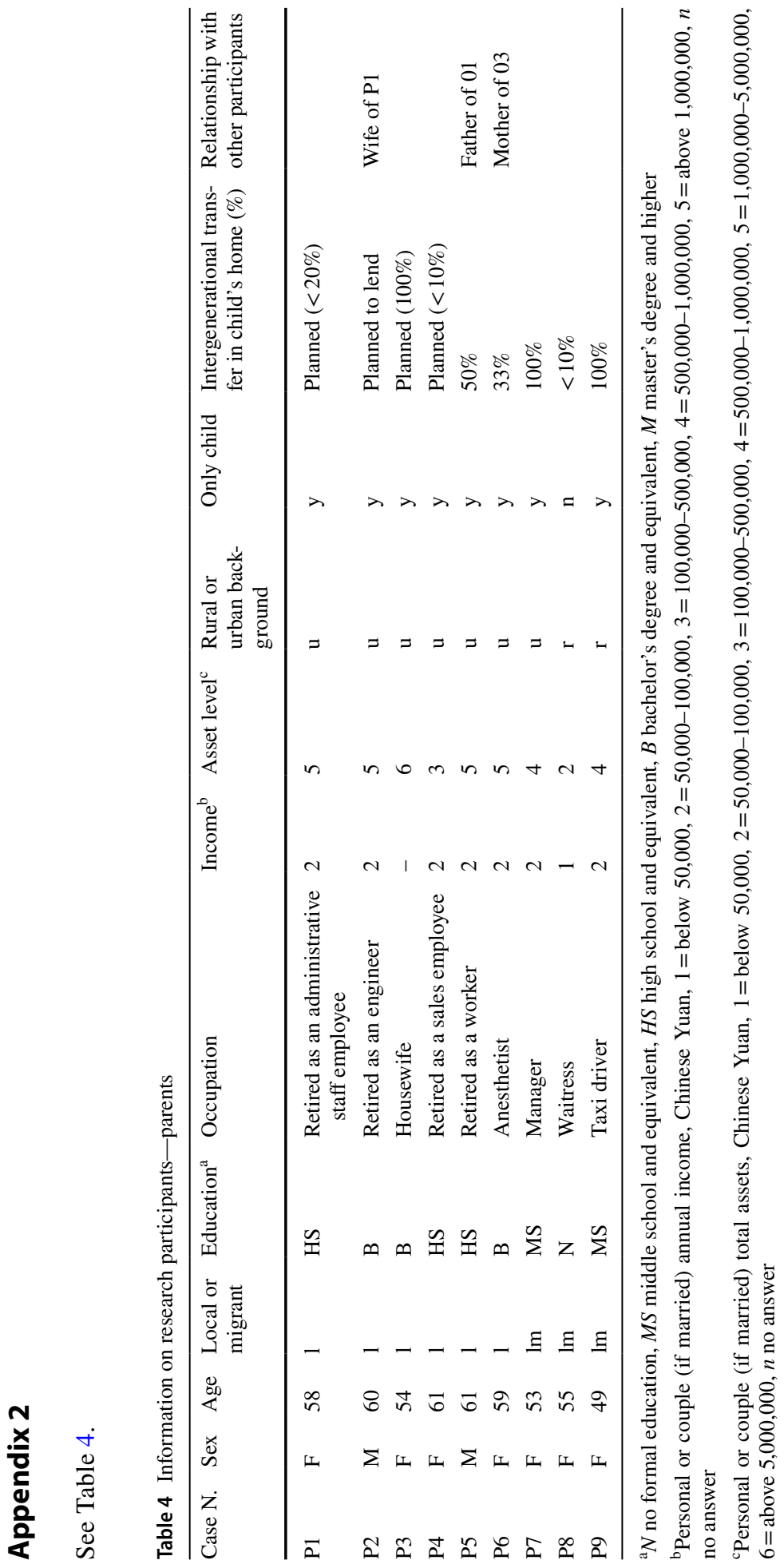




\section{References}

Albertini, M., Kohli, M., \& Vogel, C. (2007). Intergenerational Transfers of time and money in European families: Common patterns different regimes? Journal of European Social Policy, 17(4), 319-334.

ANWU (All-Nation Women's Union) and NSB (National Statistics Bureau). (2010). Key data report on the third national survey of Chinese women's social status [第三期中国妇女社会地位调查全国主要数 据报告]. http://www.wsic.ac.cn/download?guid=15bb6fa2-a6ae-4437-9628-f0523a32cbaf\&id=10229.

Blome, A., Keck, W., \& Alber, J. (2009). Family and the Welfare State in Europe: Intergenerational relationships in ageing societies. Cheltenham: Edward Elgar.

Castles, F. G., \& Ferrera, M. (1996). Home ownership and the welfare state: Is Southern Europe different? South European Society and Politics, 1, 163-185.

Croll, E. (2006). The intergenerational contract in the changing Asian family. Oxford Development Studies, 34(4), 473-491.

Cui, C., Geertman, S., \& Hooimeijer, P. (2016). Access to homeownership in urban China: A comparison between skilled migrants and skilled locals in Nanjing. Cities, 50, 188-196.

Davis, D., \& Harrell, S. (Eds.). (1993). Chinese families in the Post-Mao Era. Berkeley: University of California Press.

Deere, C. D., \& Doss, C. R. (2006). The gender asset gap: What do we know and why does it matter? Feminist Economics, 12(1-2), 1-50. https://doi.org/10.1080/13545700500508056.

Deng, W. J., Hoekstra, J. S. C. M., \& Elsinga, M. G. (2016). The changing determinants of homeownership amongst young people in Urban China. International Journal of Housing Policy, 16(2), 201-222.

Dewilde, C., \& Raeymaeckers, P. (2008). The trade-off between home-ownership and pensions: Individual and institutional determinants of old-age poverty. Ageing and Society, 28(06), 805-830.

Doling, J., \& Horsewood, N. (2011). Home ownership and pensions: Causality and the Really big trade-off. Housing, Theory and Society, 28(2), 166-182.

Doling, J., \& Ronald, R. (2010). Home ownership and asset-based welfare. Journal of Housing and the Built Environment, 25(2), 165-173.

Druta, O., \& Ronald, R. (2016). Young adults pathways into homeownership and the negotiation of intrafamily support: A home, the ideal gift. http://soc.sagepub.com/cgi/doi/10.1177/0038038516629900.

Elsinga, M., \& Hoekstra, J. (2015). The janus face of homeownership-based welfare. Critical Housing Analysis, 2(1), 32-41.

Engels, F. (1884, 2010). The origin of the family, private property and the state. London: Penguin Group.

Esping-Andersen, G. (1990). The three worlds of welfare capitalism. Cambridge: Polity Press.

Esping-Andersen, G. (1999). Social foundations of post-industrial economies. Oxford: Oxford University Press.

Fincher, L. H. (2014). Residential real estate wealth, 'leftover' women ('shengnu'), and gender inequality in urban China. Ph.d. dissertation, Tsinghua University.

Gan, L., Yin, Z., Jia, N., Xu, S., Ma, S., \& Zheng, L. (2012). Data you need to know about China-research report of China household finance survey. Heidelberg: Springer.

Goode, W. J. (1963). World revolution and family patterns. New York: Free Press.

Guo, H. M. (2011). A Gender study on housing rights of women in urban China: case study of a singleparent female domestic worker's group. In P. Kennett \& K. W. Chan (Eds.), Women and housing: An international analysis (pp. 171-247). New York: Routledge Taylor \& Francis Group.

Hareven, T. K. (1999). Families, history, and social change: Life-course and cross-cultural perspectives. Oxford: Westview Press.

Heath, S., \& Calvert, E. (2013). Gifts, loans and intergenerational support for young adults. Sociology, 47(6), 1120-1135.

Izuhara, M. (Ed.). (2010a). Ageing and intergenerational relations: Family reciprocity from a global perspective. Bristol: Policy Press.

Izuhara, M. (2010b). Housing wealth and family reciprocity in East Asia. In M. Izuhara (Ed.), Ageing and intergenerational relations: Family reciprocity from a global perspective. Bristol: Policy Press.

Izuhara, M. (2015). Towards individualising couple finance-women's housing assets and household decisions in Japan. Gender, Place and Culture, 23(7), 1003-1016.

Izuhara, M. (2016). Reconsidering the housing asset-based welfare approach: Reflection from East Asian experiences. Social Policy and Society, 15(02), 177-188.

Izuhara, M., \& Forrest, R. (2013). 'Active families': Familization, housing and welfare across generations in East Asia. Social Policy and Administration, 47(5), 520-541.

Jacobs, D. (2000). Low public expenditures on social welfare: do East Asian countries have a secret? International Journal of Social Welfare, 9(1), 2-16. 
Kemeny, J. (2001). Comparative housing and welfare: Theorising the relationship. Journal of Housing and the Built Environment, 16(1), 53-70.

Kennett, P., \& Chan, K. W. (2011). Women and housing: An international analysis. Oxon: Routledge.

LaFave, D. (2016). Family support and elderly well-being in China: Evidence from the China Health and retirement longitudinal study. Ageing International, 42(2), 142-158.

Lee, M. (2012). The one-child policy and gender equality in education in China: Evidence from household data. Journal of Family and Economic Issues, 33(1), 41-52.

Leitner, S. (2003). Varieties of familialism: The caring function of the family in comparative perspective. European Societies, 5(4), 353-375.

Lewis, J. (2002). Gender and welfare state change. European Societies, 4(4), 331-357.

$\mathrm{Li}$, L., \& Wu, X. (2011). Gender of children, bargaining power, and intrahousehold resource allocation in China. Journal of Human Resources, 46(2), 295-316.

Ling, M. (2017). Precious son, reliable daughter: Redefining son preference and parent-child relations in migrant households in urban China. The China Quarterly, 229, 150-171.

Logan, J. R., Bian, F., \& Bian, Y. (1998). Tradition and change in the urban Chinese family: The case of living arrangements. Social Forces, 76(3), 851-882.

Luo, B., \& Zhan, H. (2012). Filial piety and functional support: Understanding intergenerational solidarity among families with migrated children in rural China. Ageing International, 37(1), 69-92.

Manzo, L., \& Druta, O., et al. (2016). Supported home ownership and adult independence in milan: The gilded cage of family housing gifts and transfers. http://houwel.uva.nl/content/working-papers/hwp11 .html?origin=zIKd88h4S628aGLFszVgsA.

O'Connor, J. S. (1993). Gender, class and citizenship in the comparative analysis of welfare state regimes: Theoretical and methodological issues. The British Journal of Sociology, 44(3), 501-518.

Or, T. (2017). Pathways to homeownership among young professionals in urban China: The role of family resources. Urban Studies. https://doi.org/10.1177/0042098017714212.

Orloff, A. S. (1993). Gender and the social rights of citizenship: The comparative analysis of gender relations and welfare states. American Sociological Review, 58(3), 303-328.

Qi, X. (2017). Neo-traditional child surnaming in contemporary China: Women's rights as veiled patriarchy. Sociology. https://doi.org/10.1177/0038038516688613.

Ronald, R. (2008). The ideology of home ownership: Homeowner societies and the role of housing. London: Palgrave Macmillan.

Sargeson, S. (2012). Why women own less, and why it matters more in rural China's urban transformation. China Perspective. http://chinaperspectives.revues.org/6025.

Song, L. (2008). In search of gender bias in household resource allocation in rural China, Institute for the Study of Labor (IZA). http://nbn-resolving.de/urn:nbn:de:101:1-20080421216.

Sun, S. Q. (1996). Study on Women's inheritance rights on household property and assets in Contemporary China [当代中国妇女家庭财产继承权的微观研究]. Population and Economics, 6, 48-53.

Sun, P. D. (2012). Who will marry my daughter ?[谁来娶我的女儿?]. Shanghai: China social sciences press.

Supreme People's Court. (2011). The supreme court's explanations on a number of issues concerning the application of marriage law III [最高法关于适用婚姻法若干问题解释(三)]. Cited from http://news. qq.com/a/20110812/001033.htm. Retrieved 19 September 2017.

Toussaint, J., \& Elsinga, M. (2009). Exploring 'housing asset-based welfare'. Can the UK be held up as an example for Europe? Housing Studies, 24(5), 669-692.

Tsui, M., \& Rich, L. (2002). The only child and educational opportunity for girls in urban China. Gender and Society, 16(1), 74-92.

Whyte, M. K. (Ed.). (2003). China's revolutions and intergenerational relations. Ann Arbor: University of Michigan Center for Chinese Studies.

World Bank. (2017). Total fertility rate, (birth per woman). https://data.worldbank.org/indicator/SP.DYN. TFRT.IN?locations $=\mathrm{CN}$.

$\mathrm{Wu}$, Z. Q. (2012). Gender inequality in inheritance allocation in countryside: a case study from Wuwei, Ganshu Province [农村遗产继承中的性别不平等问题硎究———以甘肃省武威市凉州区为例]. Heihe Journal, 180, 183-184.

Xiao, S. W. (2014). Strict mother and amiable grandmother: The intergenerational collaboration and power conflicts in childrearing among urban families in contemporary China [“严母慈祖”: 儿童抚育中的代 际合作与权力关系]. Social Science Studies (06): 148-171+244-245.

Zhang, H. (2007). From resisting to 'Embracing?' The one-child rule: understanding new fertility trends in a central China village. China Quarterly, 192, 855-875.

Zhang, J., Han, J., et al. (2008). Trends in the gender earnings differential in urban China, 1988-2004. Industrial and Labor Relations Review, 61(2), 224-243. 
Zhang, Q. F. (2004). Economic transition and new patterns of parent-adult child coresidence in urban China. Journal of Marriage and Family, 66(5), 1231-1245.

Zhang, Z., Gu, D., \& Luo, Y. (2014). Coresidence with elderly parents in contemporary China: The role of filial piety, reciprocity, socioeconomic resources, and parental needs. Journal of Cross-Cultural Gerontology, 29(3), 259-276.

Zheng, W. (2005). "State feminism" gender and socialist State Formation in Maoist China. Feminist Studies, 31(3), 519-551.

Zhong, X. (2014). The purchase of intimacy: Chinese urban one-child families in housing consumption. Ph.D. dissertation, Hong Kong University. 